\title{
Bogumił Grott, Dylematy polskiego nacjonalizmu. Powrót do tradycji czy przebudowa narodowego ducha, Warszawa 2014, Wydawnictwo von Borowiecky, ss. 415
}

\author{
Aneta Dawidowicz*
}

Najnowsze dzieło Bogumiła Grotta zatytułowane Dylematy polskiego nacjonalizmu. Powrót do tradycji czy przebudowa narodowego ducha, wydane nakładem Wydawnictwa von Borowiecky, stanowi niezwykle ważną i potrzebną pozycję na polu badań nad nacjonalizmem i dziejami polskiego obozu narodowego. Dokonania Bogumiła Grotta są bardzo dobrze znane w przestrzeni naukowej ${ }^{1}$. Książka powstała

* Uniwersytet Marii Curie-Skłodowskiej w Lublinie, Wydział Politologii.

${ }^{1}$ Szerzej zob. B. Grott, Nacjonalizm i religia proces zespalania nacjonalizmu $z$ katolicyzmem w jedna całość ideowa w myśli Narodowej Demokracji, Rozprawy Habilitacyjne nr 85, Kraków 1984; idem, Katolicyzm $w$ doktrynach ugrupowań narodowo-radykalnych do roku 1939, Kraków 1987; idem, Nacjonalizm chrześcijański, Kraków 1991; idem, Religia, Kościół, etyka w ideach i koncepcjach prawicy polskiej, Kraków 1993; idem, Nacjonalizm chrześcijański, Kraków 1996; idem, Obóz narodowy a katolicyzm, „Kultura i Społeczeństwo” 1979, nr 3; idem, Rola katolicyzmu w ideologii obozu narodowego w świetle pism jego ideologów na gruncie dotychczasowych, wieloletnich zainteresowań badawczych Autora dotyczących dziejów i myśli politycznej polskiego nacjonalizmu.

Omawiana publikacja ma charakter interdyscyplinarny. Autor przedstawił mean-

i krytyki katolickiej. Zarys problematyki badawczej, „Dzieje Najnowsze” 1980, z.1; idem, Publicystyka "Zadrugi" jako jeden z przejawów krytyki kultury katolickiej w Polsce, "Studia Religiologica” 1981, z. 6; idem, Mediewalizm w koncepcjach Obozu Wielkiej Polski. Ze studiów nad religijnymi uwarunkowaniami myśli politycznej, ,Studia Religiologica" 1982, z. 7; idem, The Conception of Roman-Catholic Totalizm in Poland before World War II, ,Studia Religiologica” 1982, z. 8; idem, Waloryzacja epok historycznych i niektórych nurtów myśli europejskiej od średniowiecza po wiek XIX $w$ ideologii obozu narodowego, jako wyraz jej katolicyzacji, „Studia Religiologica” 1983, z. 9; idem, Geneza i początki formowania się poglądów „młodych” obozu narodowego na zagadnienia ustrojowe, „Dzieje Najnowsze” 1984, z.1; idem, Pojęcie narodu i jego miejsce $w$ hierarchii wartości formacji młodoendeckiej, „Przegląd Humanistyczny" 1984, nr 4. 
dry polskiego nacjonalizmu poprzez pryzmat nacjonalizmów europejskich. Był to zabieg celowy i szczególnie potrzebny, bowiem jak dowiódł Bogumił Grott, wizerunek polskiego nacjonalizmu, wyizolowany z szerszych kontekstów sytuacyjnych, byłby niepełny i zarazem wadliwy. Jak udowodnił Autor, badania nad nacjonalizmem muszą uwzględniać szeroką wiedzę w zakresie szeroko pojętej kultury i duchowości poszczególnych narodów. Stwierdzić więc należy, że recenzowana monografia stanowi istotny wkład w problematykę metodologii badań nacjonalizmów.

O potrzebie analizy tej skomplikowanej problematyki przesądzało wiele czynników. W dalszym ciągu na polu badawczym dziejów i myśli politycznej polskiego nacjonalizmu znajduje się wiele niedomówień, niezbadanych problemów i pytań badawczych. Autor analizował w szczególności skomplikowane kwestie związane z systemem aksjologicznym, kulturą i religią. Jak napisał sam Autor, takie podejście było inspirowane pracami profesora Leona Halbana, badacza współzależności pomiędzy religiami a niemieckim nacjonalizmem i kulturą niemiecką. Prezentując ideologię różnych odłamów nacjonalizmu polskiego na tle europejskim, Bogumił Grott wskazał na zasadnicze różnice pomiędzy poszczególnymi nurtami polskiego nacjonalizmu.

W książce przedstawiono dwa odrębne nurty ideowe istniejące w obrębie polskiej myśli nacjonalistycznej. Po pierwsze szeroko omówiono nurt narodowo-katolicki, po drugie zaprezentowano nurt nacjonali- zmu „modernizacyjnego", reprezentowanego przez Jana Stachniuka i Zadrugę. W pełni należy zgodzić się z opinią Autora, że nie należy mówić o jednym nacjonalizmie, lecz o wielu różnych nacjonalizmach. Przedstawienie poglądów polskich nacjonalistów zostało poprzedzone omówieniem najważniejszych nacjonalizmów europejskich, a więc przede wszystkim niemieckiego rasizmu, ukraińskiego darwinizmu społecznego, włoskiego faszyzmu, Akcji Francuskiej, frankizmu i salaryzmu. Opracowanie ukazuje więc kształtowanie i rozwój różnych idei politycznych.

Książka Grotta koncentruje się na polskim nacjonalizmie w latach 1926-1949. Przyjęte ramy czasowe są w pełni uzasadnione. Cezura początkowa to data utworzenia Obozu Wielkiej Polski, z którego wyłoniły się kadry Stronnictwa Narodowego, a także dwa odłamy narodowych radykałów ONR-ABC i RNR-Falanga. Cezurę końcową książki przyjęto nieprzypadkowo, rok 1949 stanowi datę śmierci jednego z ideologów „młodych” obozu narodowego Adama Doboszyńskiego. Warto też dodać, że również w tym samym roku (1949) został skazany na 15 lat więzienia Jan Stachniuk, co ostatecznie zakończyło jego aktywność ideową i publicystyczną. Natomiast nieco wcześniej, w 1948 roku, zostali przez komunistów zamordowani Stanisław Kasznica - komendant Narodowych Sił Zbrojnych i Lech Neyman. Jednakże rozważania Autora nie ograniczają się ściśle do wytyczonego okresu, lecz sięgają znacznie dalej i głębiej, aż do momentu kształtowania się polskiego 
nacjonalizmu na przełomie XIX i XX wieku. Myśl polityczna kształtuje się bowiem w sposób długotrwały, pod wpływem różnorakich czynników. Autor uznał więc za niezbędne przedstawienie myśli „wczesnej endecji", sformułowanej pod wpływem pozytywizmu i reprezentującej indyferentyzm religijny. Przedstawiono również poglądy Stanisława Brzozowskiego, którego można określić mianem reprezentanta „nacjonalizmu proletariackiego".

Zaletami pracy są obiektywizm i rzetelność badawcza Autora. Przejrzysta i logiczna struktura monografii stanowi jej kolejną zaletę. Recenzowana monografia w sposób całościowy przedstawia skomplikowane zjawisko nacjonalizmów. Książka składa się z pięciu rozdziałów ujętych w układzie problemowo-chronologicznym. Takie podejście pozwoliło Autorowi na klarowne przedstawienie omawianych problemów.

Nie ulega wątpliwości, że rozległa baza źródłowa umożliwiła Autorowi pełne zrealizowanie zamierzeń badawczych. Praca powstała przy uwzględnieniu bogatej i wszechstronnej bazy źródłowej, której podstawę stanowiły: pisma polityczne i publicystyczne, liczne broszury ideowe. Szeroko została wykorzystana grupa źródeł memuarystycznych w postaci pamiętników czy relacji spisywanych na bieżąco lub retrospektywnie. Autor wykorzystał także twórczość literacką i krytykę literacką. Imponująco przedstawia się lista wykorzystanych tytułów prasowych. Gruntownie wyeksploatowano zwłaszcza wydawnictwa prasowe trudno dostępne, nieznane szerzej w obiegu na- ukowym. Wykorzystano również materiały archiwalne przechowywane w zbiorach: Archiwum Akt Nowych, Biblioteki Jagiellon'skiej w Krakowie, Biblioteki Polskiej Akademii Nauk w Krakowie, Zakładu Narodowego im. Ossolińskich we Wrocławiu.

Monografia autorstwa Bogumiła Grota zajmuje poczesne miejsce $\mathrm{w}$ historiografii prac poświęconych nacjonalizmowi. Książkę cechują obiektywizm i rzetelność naukowa. Praca traktuje o zagadnieniach trudnych i ważnych, ma przy tym charakter interdyscyplinarny. Książka przybliża problematykę wciąż jeszcze niedostatecznie poznaną, wokół której narosło wiele nieuzasadnionych stereotypów, uprzedzeń, mitów. Autor walczy z tymi zjawiskami, które utrudniają poznanie i zrozumienie skomplikowanej natury nacjonalizmów. Porządkuje i wyjaśnia wiele kwestii, które w dalszym ciągu pozostają niedostatecznie zrozumiane i opisane. Wartość przedsięwzięcia profesora Bogumiła Grotta trudno więc przecenić. Opracowanie w sposób syntetyczny podejmuje wiele różnorakich wątków przez pryzmat zagadnień ideowych, kulturowych, społecznych i ekonomicznych. Autor gruntownie omawia poglądy polskich nacjonalistów dotyczące kwestii ustrojowych, politycznych, ekonomicznych, społecznych, narodowościowych, geopolitycznych. Książka przyczynia się więc do wzbogacenia refleksji nad miejscem i rolą nacjonalizmu w dziejach polskiego narodu i państwa. Omawianą książkę należy ocenić jako pozycję potrzebną w sensie zarówno naukowym, jak i praktycznym. 
Poczynione w niniejszej recenzji reflek- czych, ale i dydaktycznych. Dużą zaletą prasje żadną miarą nie oddają w pełni zawar- cy jest komunikatywność treści. Książka tości książki przygotowanej przez Bogumiła profesora Bogumiła Grotta powinna stać się Grotta. Omawiana publikacja w sposób eru- lekturą obowiązkową zarówno studentów dycyjny odsłania czytelnikowi wagę, złożo- politologii, historii, dziennikarstwa, kulność i wieloaspektowość zjawiska nacjo- turoznawstwa, socjologii, jak i wszystkich nalizmu. Opracowanie zasługuje na uwagę osób zainteresowanych tą problematyką. czytelników nie tylko ze względów poznaw- 